\title{
Responding to the commodity boom with varieties of resource nationalism: A political economy explanation for the different routes taken by Africa's new oil producers
} DOI:

10.1016/j.exis.2020.06.021

\section{Document Version \\ Accepted author manuscript}

Link to publication record in Manchester Research Explorer

Citation for published version (APA):

Hickey, S., Abdul-Gafaru, A., Izama, A., \& Mohan, G. (2020). Responding to the commodity boom with varieties of resource nationalism: A political economy explanation for the different routes taken by Africa's new oil producers. The Extractive Industries and Society, 7(4), 1246-1256. https://doi.org/10.1016/j.exis.2020.06.021

\section{Published in:}

The Extractive Industries and Society

\section{Citing this paper}

Please note that where the full-text provided on Manchester Research Explorer is the Author Accepted Manuscript or Proof version this may differ from the final Published version. If citing, it is advised that you check and use the publisher's definitive version.

\section{General rights}

Copyright and moral rights for the publications made accessible in the Research Explorer are retained by the authors and/or other copyright owners and it is a condition of accessing publications that users recognise and abide by the legal requirements associated with these rights.

\section{Takedown policy}

If you believe that this document breaches copyright please refer to the University of Manchester's Takedown Procedures [http://man.ac.uk/04Y6Bo] or contact uml.scholarlycommunications@manchester.ac.uk providing relevant details, so we can investigate your claim.

\section{OPEN ACCESS}




\title{
Responding to the commodity boom with varieties of resource nationalism: A political economy explanation for the different routes taken by Africa's new oil producers ${ }^{1}$
}

SAM HICKEY (GDI, University of Manchester), ABDUL-GAFARU ABDULAI (Legon University), ANGELO IZAMA (Independent) and GILES MOHAN (Open University)

\begin{abstract}
The institutional responses of Africa's new producers to the early 21st century commodity boom differed both between and within countries over time. Despite making similarly sized discoveries in the mid-2000s, Ghana and Uganda took different routes, with Ghana oscillating between a neoliberal modality and a soft version of resource nationalism (depending on which party was in power), whilst Uganda adopted a more consistent and robust resource nationalist position. Current explanations for varieties of resource governance tend to focus on either institutions or ideas. We argue for an alternative theoretical perspective that locates the entwined role of both institutions and ideas within a deeper analysis of a country's 'political settlement'. This offers a more compelling explanation for varied institutional responses to the commodity boom in sub-Saharan Africa, and suggests that different types of political settlements have had significant implications for how oil governance has progressed in different contexts.
\end{abstract}

Keywords: oil governance; political settlement; Africa; commodity boom; resource nationalism.

\footnotetext{
${ }^{1}$ This paper was derived from a research project undertaken within the effective States and Inclusive Development research centre, based at the Global Development Institute, University of Manchester and funded by the UK Department for International Development. All views contained herein are those of the authors and cannot be attributed to DFID. We would like to acknowledge the insightful comments of two animus reviewers and several esteemed colleagues on this and earlier drafts, including Kojo Asante, Tony Bebbington, David Booth, Laurids Lauridsen, Peter Lewis, Heather Marquette, Ricardo Soares de Oliveira and participants at the many academic and policy-related seminars where it has been presented. We are particularly grateful for the time and insights contributed by the dozens of key informants who agreed to be interviewed for this project.
} 


\section{Introduction}

When many countries in sub-Saharan Africa discovered commercial quantities of hydrocarbons during the commodity supercycle of 2004-2014, it seemed to herald a new era of 'resource nationalism' on the continent. Just as major producers in the Middle East were able to leverage the resource boom of the 1950-1970s to wrestle control of oil from major international oil companies and to finance ambitious new economic and political projects (Andreasson 2015, Steven 2008), African countries would now be able to redefine their own developmental trajectories through a nationalist agenda. From this perspective, resource nationalism offered Africa a new form of 'state capitalism' (Taylor, 2014) that could displace neoliberal modes of governmentality and secure a greater sector share of oil wealth for producer nations with developmentalist projects, as seemed to be happening amidst the 'red wave' in some parts of Latin America during the 2000s (Veltmeyer and Petras 2014). With China not only driving the commodity boom but also offering other forms of financial (and ideological) support for more statist projects of development (Jepson 2020), and given the apparent damage done to neoliberalism by the 2008 financial crisis, the global political economy conditions for a surge of resource nationalism in Africa seemed to be in place.

Now that we are able to look back at the actual responses of African producers to the commodity boom period, armed with the benefits of hindsight but also new theoretical insights into how domestic politics shapes oil governance, a more nuanced perspective inevitably emerges. This vantage point tends to undermine accounts of resource nationalism that rely on global level political economy explanations linked to shifts in demand and prices, even when nuanced by reference to ideological shifts over time (Stevens 2008). Although clearly important in establishing the structural conditions within which particular countries devise their strategic approach to oil governance, the responses of sub-Saharan African countries to the commodity boom have been more varied than such macro-level accounts would allow for. In Andreasson's (2015) study of mineral and energy markets in two established producers (Nigeria and South Africa) and one newcomer (Mozambique), for example, at least two and arguably three different varieties of resource nationalism are identified. 
As Wilson (2015) puts it, cyclical price trends may enable countries to become more bullish, but it is the nature of national level politics that condition how this plays out in particular countries. The challenge in moving beyond economistic and macro-level accounts of resource nationalism is to identify the national political and political economy factors that determine how global influences are mediated and refracted into particular types of oil governance. Current efforts to do so have tended to focus on either the role of political institutions (e.g. Wilson 2015) or of ideas (e.g. Bremmer and Johnston 2009), with both lines of enquiry significantly advancing our understanding of how varieties of resource nationalism have emerged during the commodity boom. Nonetheless, these distinct approaches tend to overlook the ways in which both institutions and ideas might matter, including through the ways that they interact in specific contexts; they also fail to consider the underlying configurations of power from which particular institutions and ideas emerge in the first place. Through a comparative analysis of two African countries that adopted different institutional and ideological responses to the commodity boom, this paper explores whether 'political settlements analysis' can offer a more insightful theoretical vantage point from which to understand and explain varieties of resource nationalism. Avoiding the reductive tendencies of some forms of political settlements analysis, we deploy a version that includes a strong focus on the role of ideology and ideas (Behuria et al., 2017; Gray 2019) and which incorporates the powerful role that transnational actors play within African politics and governance.

We do this through a comparative case-study analysis of Ghana and Uganda, whose newly found oil wealth has generated heated debates around how each country should govern oil (e.g. Siakwah, 2017; Van Alstine, et al., 2014). Despite making similarly sized discoveries at the same historical and global political economic juncture in 2007 and 2006 respectively, Ghana and Uganda have adopted significantly different approaches to governing their new oil finds. Whilst Ghana has oscillated between a largely neoliberal approach to oil governance and a 'soft' form of resource nationalism, Uganda has adopted a more consistent and robust resource nationalist position over time. This is particularly evident in the approaches that each country took to the negotiation of deals with international oil companies (IOCs) and the ways in which ruling elites managed the bureaucratic organisations responsible for oil governance in each country. These countries 
make good comparators, given that the oil finds in each context are broadly similar in terms of timing and size, whilst their political and governance contexts are markedly different. This is clearly the case when one looks at formal modes of governance, whereby Ghana outscores Uganda on every accepted measure of democracy and good governance (Table 1). More importantly, the countries also differ in terms of the less formal configuration of political power that underpins these institutional arrangements, whereby Ghana has been characterised as a 'competitive clientelist' political settlement, as compared to Uganda's more 'dominant' form (Levy 2014; Whitfield et al., 2015). These different types of political settlement generate different incentives for elites around the governance of development and they are also profoundly shaped by and help to shape competing ideas on how development should proceed. The paradigmatic ideologies around which political elites mobilise in each case differ from each other, whether in terms of the stronger focus on 'national unity' in Ghana than Uganda, or in terms of the level of ideological contestation between competing elite factions within each case. The form that multi-party competition has taken in Ghana as been underpinned both by formal constitutional arrangements since 1992 and the prolonged process of elite bargaining that took place up until the mid-1990s (Oduro et al., 2014). This established that the rules of the game for exchanging power would actually be respected and helped institutionalise a two-party system based (albeit somewhat loosely) around the alternative neoliberal and more statist programmes offered by the National Patriotic Party and National Democratic Congress respectively (Ninsin 2006). Whilst these ideologies also (co)exist within Uganda's political discourse and development strategies, the differing configurations of power here mean that they are not openly contested or subject to variation in the same way as in Ghana, given that the ruling National Resistance Movement has remained in office since taking power in 1986. Employing a paired comparison of these 'most-likely' cases and a process-tracing approach (George and Bennett, 2005), we explore how each country took these different routes to oil governance - focusing on the early discovery phases - during the commodity boom and test the extent to which a political settlements analysis can help explain this variance.

The next section briefly recaps current debates around oil governance, with a particular focus on explanations for different forms of neoliberal-resource-nationalist approaches adopted during the commodity price boom. We identify problems with current 
explanations and argue for an alternative perspective that can uncover the forms of politics and power relations that shape institutional and ideological responses to oil governance. This section also sets out the methodological approach adopted in more depth. Section 3 introduces the two cases and discusses their alternative approaches to oil governance, with a particular focus on deal-making with international oil companies and the political management of the oil technocracy. Section 4 analyses these different approaches to resource nationalism, before the final section concludes and sets out the implications of the argument pursued here.

\section{Responding to the commodity boom in sub-Saharan Africa: Varieties of resource nationalism}

\subsection{Conceptualising resource nationalism: Beyond institutions?}

One of the key claims sparked by the emergence of Africa's new producers during the commodity boom era of 2004-14 was that this had catalysed a new era of 'resource nationalism', as had occurred during the previous commodity supercycle in the mid-1970s (Vivoda, 2009). Here, resource nationalism was defined as "the tendency for (nation) states to assert economic and political control over natural resources found within its sovereign territory" (Childs, 2016: 539), and generally contrasted with a more neoliberal approach to oil governance. Where resource nationalism would involve the state playing a significant role in securing ownership of the resources, the means of generating wealth from this resource and in claiming this wealth itself, a more neoliberal approach would involve less state involvement beyond a mutually agreed taxation regime and relatively stronger leadership role for international oil companies. With neoliberalism apparently facing an existential threat in the aftermath of the global financial crisis of 2007-08, some scholars sought to go beyond this "reductive dichotomy" in favour of recognising the emergence of “'hybrid' or 'post-'neoliberal forms of governance" (Childs, 2016: 541). Others constructed typologies of the varieties of resource nationalism that emerged during the commodity supercycle, often in ways that help capture at least some of this hybridity. For example, two of the variants of resource nationalism identified within Bremmer and Johnston's widely cited (2009) typology include significant elements of a market-driven, neoliberal approach, namely the 'soft' variety identified with OECD producers such as Australia and the United 
Kingdom, and the 'economic' variety apparently witnessed in Kazakhstan and South Africa (Bremmer and Johnston, 2009; also Andreasson, 2015).

Problematically, these schemas tend to separate out developed from developing countries, incorporating a north-south binary to inform distinctions between different types of resource nationalism that should instead be parsed in relation to the ideological and political projects at work in particular cases, irrespective of geography. This is apparent in Bremmer and Johnston's (2009) somewhat arbitrary distinction between the 'economic resource nationalism' they associate with countries based in the global south and the more civilized 'soft' version practiced by OECD countries such as Australia and Canada. It also informs Wilson's (2015) schema that we discuss in the next paragraph, whereby low-income countries are classed as 'rentier' and high-income countries uniformly defined as 'liberal market'. Such stereotyping also overlooks the variety that exists within these broad country categories; this is a particular problem for sub-Saharan Africa given the region's relative lack of coverage in debates over resource nationalism; for example, Wilson's important (2015) study only includes one country from sub-Saharan Africa in its sample of ten countries. Instead, we would argue that it makes sense to think about resource nationalism in genuinely global terms and with a focus on the actual policy measures involved rather than on which types of countries are promoting them. In this paper then, and also informed by the sense that neoliberalism's death knell was arguably sounded too soon (Sheppard and Leitner 2010), we refer here to a continuum of resource governance that operates between the two poles of 'hard' resource nationalism at one end and neoliberalism at the other, with 'softer' and more hybrid varieties of resource nationalism lying between them. In line with Pedersen et al (2020)'s study of Tanzania, we find this to be a useful way of distinguishing between different approaches both between and within countries over time.

Efforts to explain the extent of resource nationalism, rather than define it, have recently moved away from economic to political explanations. From an economic perspective, the cyclical nature of resource nationalism reflects price changes, whereby during periods of price appreciation bargaining power shifts from firms to producer country states.' However, Wilson (2015) rightly suggests that whilst cyclical price trends may enable countries to become more bullish, it is political institutions that condition how this plays out. Wilson argues that there are three types of political institutions that shape resource nationalism. 
First, rentier states, where natural resources are a leading sector and where rents are centralised to allow for social welfare redistribution and/or political patronage. Second, are developmental states, where the state assumes an interventionist role in economic transformation and directs production and taxation into various forms of downstream industrialisation and job creation. Third, are more liberal states that use market mechanisms to capture economic resources from firms but do not get directly involved in production or purposive policy.

Wilson's schema is useful for emphasising the need for a political explanation of how countries respond to resource booms; as argued earlier, without this we are left with an economically reductive explanation for political behavior and with little basis on which to explain variance between similar countries operating in similar structural conditions. However, and in line with the broader 'post-institutionalist' turn within analyses of natural resource governance and beyond in development studies (see below), we would argue that a focus on institutions alone cannot explain why different forms of resource nationalism emerge in different contexts. Rather, we need to examine the underlying configurations of power that generate certain kinds of institutions in the first place and also examine the role of ideology and ideas in shaping elite policy orientations towards oil governance. An additional problem is that Wilson implies that institutional types are static and singular, rather than potentially co-existent and dynamic, as with his distinction between 'rentier' and 'developmental' modes of resource nationalism (2015: 404). As we will see here, this overlooks the extent to which both forms can alternate and/or co-exist within the same country contexts.

The institutionalist paradigm that has dominated much of the literature on resource governance over the past three decades has long been critiqued, but only in recent years has a viable alternative emerged. Charges against new institutionalist thinking include the failure to explain the conditions under which institutions emerge, an inability to explain why the same forms of institution function so differently in different contexts (Rodrik, 2004), and a reliance on path dependency explanations for institutional change that overlook other drivers, including inter-elite struggles (Portes, 2006: 238). Recent scholarship on natural resource governance has started to address these challenges, with Terry Karl (2007) arguing that whether 'institutions' underpin resource-led growth depends on the type of politics 
that produce them. In Amy Poteete's (2009) critique of new institutionalist readings of how Botswana avoided the resource curse (Acemoglu et al., 2003), she argues that Botswana did not have particularly strong institutions at the moment when diamonds were discovered; rather, it was moved towards developing these through the ideological commitment of a particular ruling coalition to governing diamond wealth effectively and in the national interest. The proposed causality here runs from the configuration of power (in ideational as well as material forms) through institutions to development, with political coalitions acting as the mechanism through which these relationships are mediated (e.g. Portes, 2006; Poteete, 2009).

Recent work on 'political settlements' has codified these insights into a coherent conceptual framework (Khan, 2010, 2017; Whitfield et al., 2015), whereby a political settlement is defined as "the balance or distribution of power between contending social groups and social classes, on which any state is based" (Di John and Putzel, 2009: 4). A political settlement exists where a process of elite bargaining has led to institutional arrangements that ensure the distribution of resources in line with the prevailing distribution of power among elites (Khan and Jomo, 2000). The organisation of power within the ruling coalition is particularly important in shaping prospects for development (Khan, 2010, 2017; Kurtz, 2009; Slater, 2010). Where ruling coalitions are able to either repress or co-opt rival sources of power, they can secure a dominant party political settlement, with relatively little prospect of power changing hands, even though elections may be held. Within competitive clientelist settlements, on the other hand, ruling coalitions face a credible challenge from excluded elite factions and considerable pressures from lower-level actors to maintain their loyalty. Dominant party settlements may encourage political elites to adopt a longer-term time-horizon with regards to making investments in institution building (Kurtz, 2009), and also offer ruling coalitions the capacity to implement such projects free from the constraints of strong factions operating either outside or within the ruling coalition (Khan, 2010). Importantly, in the case of oil, this includes the capacity to control the rent-seeking activities of other elites (Kelsall, 2013). Unless the political institutions involved in organising contests for political power and the bureaucratic institutions involved with resource allocation are sufficiently robust, this may be more difficult in competitive clientelist settings, where the perennial threat of being removed 
from power may mean that "there is little incentive for political leaders to invest in the longterm task of building bureaucratic capability", as opposed to maintaining power through "the discretionary allocation of rents: market privileges; patronage public employment; single-sourced procurement contracts; preferential access to natural resources" (Levy, 2014: 40).

When applied to the realm of natural resource governance, there is increasing evidence that these new perspectives can provide compelling explanations for how countries actually govern their new oil and gas finds (Bebbington et al., 2018; Hickey and Izama 2016; Karl, 2007; Lewis, 2007; Macuane et al., 2017; Mohan et al., 2018; Poteete, 2009; Salimo et al., 2020; Tyce, 2020). For example, Macuane et al. (2017) reveal that Mozambique's political and economic downturn since the discovery of major gas finds was directly shaped by the ways in which the political settlement has been organised and rentmobilisation controlled by the ruling elite. Importantly, Bebbington et al.'s (2018) analysis of resource governance in Latin America and sub-Saharan Africa shows that whilst the incentives that are generated by certain configurations of power play a critical role in shaping resource governance, the ways in which political elites govern natural resources is also strongly shaped by the role of ideologies and ideas. As Watts (2004) has argued, new oil discoveries can reshape the political imaginaries of political actors at multiple levels, often in a resource nationalist direction, although not necessarily in a developmentalist one. Ward (2009) discusses the 'psychic benefits' of resource nationalism, meaning that developmentalist discourse can play a legitimating function in representing regimes as supporting the national interest, when in fact the benefits are skewed to particular segments of society (Childs, 2016).

From a theoretical standpoint, we would argue that ideas are integral to the ways in which political settlements are formed, negotiated and maintained, and to the effects they have, both in terms of natural resource governance (Bebbington et al., 2018) and also more broadly (Gray, 2019; Lavers 2018). The ways in which ideas emerge and get (re)negotiated by political actors are both profoundly shaped by the configuration of power within which these actors operate and this also, in turn, help to shape this configuration of power itself. According to Hazel Gray (2019: 9), "political commitments to particular political ideologies are a potentially significant force that structures institutions but also the distribution of 
power", primarily by shaping how legitimate the claims of different groups are perceived to be. This also matters for the direction of policy: different ideologies provide distinct logics of state-led projects of redistribution and influence alternative processes of economic change, thus "providing a dialectical understanding of the relationship between ideologies, power, and institutions" (op cit.). In applying this ideational version of political settlements analysis, we hope not only to shed more light on our specific cases but also to further advance this increasingly influential body of theory.

\subsection{Researching the politics of natural resource governance}

In order to explore whether this ideational version of political settlements analysis could provide a more insightful approach to understanding the differing responses that African countries made to the commodity supercycle, we undertook a comparative casestudy analysis of Ghana and Uganda. The two countries make good comparators regarding the nature and timing of their oil finds: both identified recoverable amounts of oil at around the same time and at a similar level of economic value (see Table 1), and both have also engaged closely with the same international oil company, namely, Tullow. The relevance of this country comparison is further underpinned by the fact that these processes were taking place over the same timeframe, and therefore within the same global regime (e.g. with regards to oil prices), and that one IOC was involved in both contexts. We control for the fact that Ghana has moved more swiftly than Uganda to production, by focusing only on those upstream aspects of oil governance that both countries had engaged during the relevant historical period (2004-14). We also directly explored the potentially salient difference arising from the fact that Ghana's finds are offshore, whereas Uganda's are onshore; as discussed later, we found that political rather than geographical differences helped explain the comparative quality of the deals that each country was able to secure. The formal nature of governance in each country renders them interesting comparators, from an institutionalist perspective. According to mainstream indexes of democracy and governance, Ghana far outstrips Uganda along virtually every dimension (see Table 2). Ghana not only records much higher levels of per capita income and human development, 
but is also judged to be much more democratic and effectively governed than Uganda, which exhibits higher levels of corruption and authoritarian tendencies.

Table 1: Oil in Ghana and Uganda

\begin{tabular}{|lll|}
\hline & Ghana & Uganda \\
\hline Major discovery & 2007 (offshore) & 2006 (onshore) \\
\hline Production begins & November 2010 & 2020 (estimated) \\
\hline Projected lifespan & c.2030 & c.2040 \\
\hline Volume (recoverable) & 2 bn+ barrels & $1.2-1.7$ bn barrels \\
\hline $\begin{array}{l}\text { Economic value of oil (if } \\
\text { maximum production } \\
\text { potential is realised) }\end{array}$ & $3-4 \%$ GDP pa & $6-7 \%$ GDP pa \\
\hline
\end{tabular}

Table 2: Ghana and Uganda - institutional comparisons ii

\begin{tabular}{|lll|}
\hline & Ghana & Uganda \\
\hline Development indicators & \$1,570 GDP per capita & \$500 GDP per capita \\
& 135/187 HDI (medium) & $161 / 187$ HDI (low) \\
& Growth: 5.6\% (2001-10) & Growth: 7-8\% (2001-10) \\
\hline $\begin{array}{l}\text { Democracy (data from Polity } \\
\text { IV 2010) }\end{array}$ & Multi-party since 1992 & Multi-party since 2005 \\
& Democratic: 8 Polity IV & Closed anocracy: -1 Polity IV \\
\hline $\begin{array}{l}\text { Governance indicators (WGI, } \\
\text { 2006) }\end{array}$ & Voice and accountability: & Voice and accountability: \\
& 0.37 & -0.42 \\
& Government effectiveness: & Government effectiveness: \\
& 0.11 & -0.48 \\
& Rule of law: 0.00 & Rule of law: -0.34 \\
& Control of corruption: 0.02 & Control of corruption: -0.75 \\
\hline
\end{tabular}

Most importantly, the two cases enable us to test the propositions generated by a political settlements perspective, as each represent a different type thereof. As discussed in more depth below, Ghana has since the early 1990s been characterised by a high degree of competition between elite factions that formed around two main political parties. Tightly fought elections and relatively frequent turnovers mean that ruling coalitions are continually in a vulnerable position vis-à-vis alternative coalitions with the capacity to wrest 
power from them. Meanwhile, the advent of oil appears to have further intensified interelite competition for power (Mohan et al., 2018; Whitfield et al., 2015), threatening a vicious rather than virtual spiral with regards to the expected relationships between political competition and institutional development. Uganda, meanwhile, represents a 'dominant' form of political settlement, whereby the ruling coalition has ensured its longevity by actively seeking to co-opt and/or repress rival elite actors and factions. The current president has been in power since 1986, and whilst there has been little sign of a sustained state-building project, some effort has been made to protect certain bureaucratic enclaves within economic governance from political interference in ways that have had developmental outcomes (Golooba-Mutebi and Hickey, 2016; Whitfield et al., 2015).

Selecting cases according to typological criteria helped establish theoretical propositions on natural resource governance that flow from a political settlements perspective and which could be tested through between-case analysis (George and Bennett 2005: 149; Gerring, 2007). To ensure rigorous within-case analysis, process-tracing was undertaken to see if the key outcomes of interest could be plausibly tracked back to specific causal mechanisms emanating from the incentives and ideas generated by each political settlement. Deploying the strengths of these two methodological approaches helps reduce the risk of mistaken inferences through within-case analysis and enables us to build contingent explanations through comparative analysis (George and Bennett, 2005). As noted above, we focus only on processes and outcomes that are directly comparable between the two cases. Two indicators were chosen to represent the type and extent of resource nationalism being pursued in each case, and also within each case over time. First was the formulation and implementation of the fiscal regime, particularly in terms of production sharing agreements, in line with the emphasis in the resource nationalist literature on how hard governments try to secure a high financial take in such agreements (Bremmer and Johnston, 2009). This involved examining the actual deal-making processes that each government undertook with IOCs and the outcomes derived from these. ${ }^{\text {iii }}$ The second main indicator was the extent to which respective ruling coalitions invested in building and protecting the capacity of bureaucratic enclaves with responsibility for governing oil in the national interest. The role of such 'pockets of effectiveness' has been strongly highlighted in the literature as being a key indicator of how committed and capable 
a government is of ensuring statist control of oil governance (Hertog, 2010; Hout, 2013 Lewis 2007).

Methodologically, we undertook over 60 interviews with key stakeholders in each country between 2013 and 2015; wherever possible, we used documentary and statistical evidence from other sources to triangulate with our interview data, such as comparative reports on the share taken by African governments in comparable deal-making processes. However, the qualitative method was the only viable means of getting inside the 'black box' of policy- and deal-making within the notoriously secretive world of oil governance. The fact that we were able to interview officials from government and oil companies who were directly involved in the oil negotiations, as well as close observers of these processes from parliaments and civil society, further enhances the reliability and (internal) validity of the evidence presented here.

\section{How different political settlements shape the governance of oil in Africa}

This section sets out how each of our case study countries can be characterised in terms of their political settlements, before arguing that these political settlements directly shaped the institutional approach that each took to governing oil during the resource boom period.

\subsection{Comparing competitive clientelist Ghana with dominant party Uganda}

Following the political instability of the 1970s, Ghana shifted towards a dominant party political settlement under Jerry Rawlings' Provisional National Defence Council (PNDC) in the early 1980s (Oduro et al., 2014). The stability and elite consensus around economic policy-making that this enabled helped establish the conditions for a successful period of economic growth, including through protecting the role of the economic technocracy. The return of multi-party politics in 1992 saw a steady transformation towards a competitive clientelist settlement, mediated not only through the formal constitutional process, but also informal inter-elite bargaining that secured agreement amongst powerful actors regarding the rules for exchanging political power (Mosley, 2012). These conditions provided the basis for maintaining peace, an impressive rate of economic growth and also a sense of democratic deepening, as evidenced by three largely peaceful turnover elections in 2000, 
2008 and 2016. This has led some to argue that politics in Ghana has become increasingly programmatic (Lindberg and Morrison, 2008), with voters able to choose between the competing ideological platforms of the broadly liberal democratic National Patriotic Party (NPP) and broadly social democratic National Development Congress (NDC).

However, Ghana's current political settlement appears to be undermining the country's capacity to overcome the next level of development and institutional challenges. This includes moving from economic growth to structural transformation (Osei et al., 2018; Whitfield, 2012) and tackling deep-seated socio-economic equalities, particularly between the north and south of the country (Abdulai and Hickey, 2016). Since 2000, tightly fought elections seem to have induced short-term time-horizons amongst ruling elites, resulting in a highly politicised public bureaucracy. Elections generate a significant turnover of jobs on partisan grounds and massive levels of public spending that undermine macroeconomic stability and the autonomy of technocrats (Abdulai and Mohan 2019; Killick, 2008;). From this perspective, competitive politics has deepened rather than displaced clientelist forms of politics in certain respects (Gyimah-Boadi and Prempeh, 2012; Keefer, 2007).

Uganda increasingly represents a 'weak' version of the dominant party political settlement that was established when the current incumbents took power in 1986 (Golooba-Mutebi and Hickey, 2013). Led by President Yoweri Museveni, the National Resistance Movement (NRM) established political stability through building a largely inclusive ruling coalition that co-opted political elites from most ethno-regional groups (Lindemann, 2011). Unopposed by organised social and political groups, and apparently driven by a genuine ideological commitment to democracy and development, President Museveni undertook a series of radical economic and political reforms, which, alongside major external support, had a largely positive effect in terms of economic growth and poverty reduction (Dijkstra and van Donge, 2001). This was underpinned by a deal between the executive and leading bureaucrats that gave the Bank of Uganda and the Ministry of Finance the autonomy and capacity to operate as 'pockets of effectiveness', which in turn was critical to establishing the conditions for macroeconomic stability and growth (Tumusiime-Mutebile, 2010). However, this commitment to state-building was not widespread and high levels of corruption soon came to permeate the country's system of 
governance. Uganda's economic technocracy has come under increased pressure as the perceived threat to the ruling coalition has heightened since the return of multi-party politics in 2005 , as illustrated with the increased macroeconomic instability that followed the 2011 elections (Golooba-Mutebi and Hickey, 2016). The president has sought to reassert his dominance in the face of these competitive pressures, including through the removal of presidential term limits in 2005, and there is a strong sense that he is unlikely to depart power via the ballot box, despite tightly fought elections in both 2006 and 2016 .

\subsection{Deals or rules? Different political settlements, different approaches}

How Ghana and Uganda each initially approached the governance of their new oil finds in 2006-07 tended to reflect these differences in political settlement type, rather than the nature of their political institutions per se (cf. Wilson, 2015). Faced with closely fought elections, Ghana moved from discovery to production at record-breaking speed (GyimahBoadi and Prempeh, 2012), with both government and IOCs no doubt tempted by the lure of high oil prices. It is also likely that the NPP government was worried about the negative impact of the global food crisis and a rising public sector wage bill at the time. However, our evidence strongly suggests that political settlement dynamics were the key driver of this rapid move to production, with the NPP's primary motives being to secure the cash and electoral kudos. Indeed, the rising wage bill at the time was in itself an outcome of electoral pressures (Abdulai and Mohan, 2019).

The NPP government in its second term (2004-08) was repeatedly warned of the dangers of rushing to production, including by its own oil technocrats:

Politicians, particularly when they realised that it is election year, it becomes a bit of a problem, sometimes politicians want ... to be personally involved in the negotiations. Sometimes, you look at the composition of the negotiation team and you realise that they want to take centre stage .... politicians sometimes want projects to be timed according to their political timetable ... so there are these clashes technical persons have with the politicians ... their level of haste [sometimes] results to outcomes that are very detrimental to the interest of the country (Interview, Energy Ministry official, 29 August 2014). 
There is also evidence that NPP pushed IOCs to their joint venture partners to fast-track their work, even if this amounted to compromising some environmental standards; according to the chief operating officer for Kosmos in an interview for Upstream Magazine,

a strategic decision was made to pursue a parallel, fast-track appraisal and development strategy due to a combination of factors, including the size of the discovery, the project's importance to the partners, and 'strong encouragement from Ghana's government' (cited in Gary, 2009: 24).

Some concerns have been privately expressed that the government, eager for cash, was pushing the consortium to do a "'quick and dirty' plan that would cut corners to exploit the field as quickly as possible" (Gary, 2009: 24). Despite calls from Norway and others for a restructuring of the sector following the discovery of commercial quantities of oil in 2007 (Heller and Marcel, 2012), it was not until 2011 that parliament moved to establish a new regulatory body, known as the Petroleum Commission (PC). ${ }^{\text {iv }}$ The NPP's affinity with marketdriven development was further apparent in the rush to enable IOCs to exploit its resources as fast as possible rather than first generating the capacity for the state to pursue a more resource nationalist approach. Indeed, oil production started before significant progress had been made in addressing the chronic lack of bureaucratic and technical capacity in Ghana along the whole oil value chain (World Bank, 2010). To some extent, this urge continued under the NDC government, which assumed office in January 2009. According to one senior oil bureaucrat in Ghana, the NDC was determined to ensure that oil revenues were flowing in time to help secure a second term at the 2012 poll,

Government came in [and said] we need to have first oil this year. We kept telling government that, look, it is dangerous to have first oil in the year 2010. If anything at all, we can shift to the first quarter of 2011. 2010 came, we had the first oil, we all celebrated, we were all happy. At the end of 2011, how much did government get? Zero! (Interview, 27 August 2014.)

However, and as explored in greater detail below, the NDC government did seek to reframe the debate over oil in more resource nationalist terms and to (re)empower GNPC to play a larger role in commercial as well as regulatory activities. 
Uganda, in contrast, placed its negotiations with IOCs on hold in 2007, preferring to get new rules in place first through the 2008 National Oil and Gas Policy (Kashambuzi, 2010: 7). As one international oil expert then working in Uganda noted,

They (Government of Uganda) said that they were not going to do any further oil licensing without getting things in place first ... that was a very brave statement and it has been followed-up politically (Interview, Development Advisor, 14 April 2014).

Later rounds of contracting were similarly put on hold until the 2013 Upstream and Midstream Bills (de Vibe, 2013), and the 2015 Public Finance Act were passed. Confident of being in power for a prolonged period, the government of Uganda (GoU) was happy to move slowly in its negotiations with IOCs, in order to ensure that it gained more favourable deals (an issue that we return to below). As discussed elsewhere (Hickey and Izama, 2016), this resource nationalist agenda extended to an insistence that first oil would be reserved for an oil refinery, rather than an export pipeline, to enable value addition to take place within the context of a more ambitious and statist national developmental agenda (RoU 2010).

An initial analysis of how Ghana and Uganda undertook the challenge of oil governance during the commodity price boom suggests that the character of the political settlement has been influential in both cases, particularly in terms of the time horizons generated in each case. Ideas also played a role here, with the discovery of oil apparently helping to catalyse the return of a more statist and transformative development agenda in Uganda (Hickey, 2013), whereas in Ghana a more neoliberal sensibility was in evidence under the NPP until late 2008, before the NDC made some moves towards (re)establishing a more nationalistic agenda, as indicated by the consistent focus on this within presidential State of the Nation addresses (Childs and Hearn, 2017). The following section explores the actual process through which each country approached the deal-making process with international oil companies, as a critical window through which to explore both the extent and the drivers of resource nationalist ambitions in each case.

\section{Varieties of resource nationalism? Getting good deals from international oil companies}


A comparative review of the upstream fiscal regimes established within oil-and-gasproducing countries in sub-Saharan Africa during the first half of the commodity supercycle shows that Ghana has performed relatively well in securing a profit share of 38-50 percent from its production-sharing agreements with IOCs, which is above average for the continent (Amoako-Tuffuor and Owusu-Ayim, 2010). ${ }^{\vee}$ However, Uganda has performed notably better in these terms, with a government take of $43.5-66$ percent that is more in line with global averages (ibid.). The sense that Uganda was performing better than Ghana in this aspect of oil governance, if not in terms of actual production, was confirmed by our interviews with the representatives of an oil company that was making deals with both governments over the same time period. According to one company source, "Uganda will gain 80 percent per barrel, but it is only 60 percent in Ghana. Government of Uganda's revenue share is one of the highest in Africa - see IMF report on that" (interview, 7 November 2013). A report on Uganda from an independent advocacy group found that:

The improved financial terms in the contracts could earn the state hundreds of millions of dollars in additional revenue and secure the government a very high percentage of the oil profits. Uganda is likely to receive between $80 \%$ and well over 90\% of revenues, after costs have been recovered (Global Witness, 2014: 6-7).

Further evaluations by the IMF and a consultancy firm hired by GoU support the extent to which Uganda has performed favourably in comparison with its international counterparts, including Ghana, in gaining good deals. Moreover, Uganda managed to limit the level of cost recovery that can be claimed by IOCs to 65 percent of their total investments, while Ghana has not secured any limit (Amoako-Tuffuor and Owusu-Ayim, 2010). vi

In line with the methodological approach outlined earlier, we now trace the processes through which each country arrived at these different types of deals, and explore whether these could be plausibly linked to the different types of political settlement that prevail in each context. We find that the extent to which each country was able to secure good deals rested heavily on whether ruling elites were prepared to invest in building and protecting high levels of bureaucratic capacity in the sector of oil governance, and to enabling oil technocrats within these bureaucratic 'pockets of effectiveness' to perform 
their role without undue political interference. The extent of the commitment to building and protecting the capacity of bureaucratic enclaves to hold IOCs to account, protect the national interest and govern oil as a national resource, can be taken as an important indicator of the extent of resource nationalism.

\subsection{Getting good deals in Ghana? The perils of contracting under competitive clientelism}

The early 1980s saw Ghana undertake a restructuring of the energy sector to accelerate the pace of petroleum exploration, with the nationalistic and cash-strapped PNDC government concentrating power in the Ghana National Petroleum Corporation (GNPC). The GNPC was mandated to be both industry regulator and commercial entity, somewhat along the lines of Brazil's Petrobras, from which it initially received technical assistance (Heller and Marcel, 2012). It was led by Tsatsu Tsikata, a leading PNDC ideologue and close ally of the then head of state, who used his political connections to take over the functions of the Ministry of Fuel and Power's Petroleum Department and protect the autonomy of GNPC (Prempeh and Kroon, 2012: 10). Significant efforts were made during the mid-1980s to develop the capacity of the GNPC to undertake exploration and attract foreign investment. Staff members were sent abroad to acquire higher degrees in petroleum-related subjects, including to Canada, the United Kingdom, Romania, and Russia (interview, GNPC official, 27 August 2014), and attached to IOCs in order to build capacity around project management and contract negotiations. A senior official at the energy ministry recalled how staff "were all looking for work at GNPC; there was really a lot of motivation" (interview, 29 September 2014). Such motivations flowed from the professional development opportunities and relatively high salaries on offer at GNPC, as well as alignment with PNDC's ideological commitment to development at the time. Most informants stressed that GNPC became known as a high-capacity institution during this period: "GNPC had a strong calibre of workforce ... to the extent that they were even able to undertake oil exploration in territories like Angola and Equatorial Guinea" (interview, energy ministry official, 29 August 2014; also Prempeh and Kroon, 2012: 10). One retired GNPC official emphasised the Corporation's organisational competence with reference to its ability to drill more difficult wells than any other West African country had been able to drill before (interview, 27 August 2014). International industry representatives corroborate this view of GNPC as a pocket of effectiveness during this period. For example, one key industry activist reported 
that joint venture partners were so impressed with the industry expertise of GNPC's director of exploration and production that they warned that "...look, you guys should take care of that man; any company in this world will want to appoint him as CEO" (interview, civil society activist, 26 August. 2014).

However, when no commercially viable oil deposits were discovered during the 1980s, GNPC started to diversify into non-core oil and gas activities. This, and Tsikata's closeness to the president, led to claims that the GNPC leader was effectively using it as a 'personal vehicle' for accumulating wealth (Opoku, 2010). On taking power in 2001, the new NPP government saw GNPC as a stooge of its political rival and undertook a significant restructuring of the Corporation. Tsikata was imprisoned and 90 percent of GNPC staff were removed, in a move seen as politically motivated. Indeed, one ministry official was very emphatic that this restructuring process was more of a 'political agenda rather than a developmental agenda', in that because

the head of the GNPC was very well aligned to the [NDC] government that lost power, the incoming [NPP] government just simply threw away the baby with the bath water (interview, energy ministry official, 29 August2014)

The adverse implications of this perceived politically driven restructuring processes were strongly highlighted by one retired GNPC official:

GNPC built capacity enough, but unfortunately when NPP came, they said GNPC was not doing anything. They sacked 90 percent of us ...... They sacked 90 percent of the engineers, including one who is now a current deputy minister for energy. All the supporting staff were fired .... so when you sack all the [supporting] people, who is going to do it? So you see, we built the capacity, but we destroyed the capacity with politics (interview, Petroleum Commission, 26 August 2014).

As a result, oil production started in Ghana when there was an "acute shortage of technical skills at all levels" along the oil value chain, and when capacity needs of various state institutions responsible for the management of the sector were "considerable" (World Bank, 2010: 1-2). The NPP overturned the fiscal regime set in place by the PNDC, which 
sought to obtain a state share of net-oil of between 65 percent and 55 percent, in favour of more investor-friendly terms of between 55 percent and 45 percent (interview, former energy minister, April 2014). This attracted increased investment from IOCs and also led to a fierce battle between the NPP and the GNPC, including over deals that seemed to benefit companies with direct links to the ruling party and which were worked through presidential advisors, rather than GNPC technocrats. Although the GNPC has managed to protect meritocratic processes of recruitment within the technical cadre, ${ }^{\text {vii }}$ insiders suggest that the GNPC has become more exposed to the deepening of clientelism that occurred under increasingly tight electoral competition during the 2000s in Ghana (Whitfield, 2012). This is particularly apparent in the tendency to allocate elites from the oil-producing region to GNPC's governing body. These appointments are under presidential control and "certainly political"; junior-level posts are also determined by "whom you know ... The junior level is more of cronyism" (interview, energy ministry official, 29 August 2014).

The fortunes of the GNPC were reversed somewhat after 2008, with the NDC returning to power and investing heavily in recruitment and capacity-building projects within the GNPC. With GNPC re-empowered, and Tsikata acting as a presidential advisor, viii a more nationalist approach to governing oil and gas was re-asserted. This shift is reflected in the royalty rates for agreements that were actually signed over this period: between 2002 and 2006 this varied from 4 to 5 percent, before doubling to 10 percent since 2008 (Figure 1). The improvement in the government's take since 2008 is particularly impressive when analysed in relation to the state's additional participation, which has seen an improvement from an average of 4 percent during 2002-06 to around 13 percent during 2008-14 (also Amoako-Tuffuor and Owusu-Ayim, 2010: 14). Although driven in part by the derisking of investments that generally follows the discovery of commercial quantities of oil, the return of more capable civil servants to the negotiating table, backed by a more resource nationalist government, helped to secure more favourable terms for government.

\section{Figure 1: Royalty rates for Ghana's oil agreements}




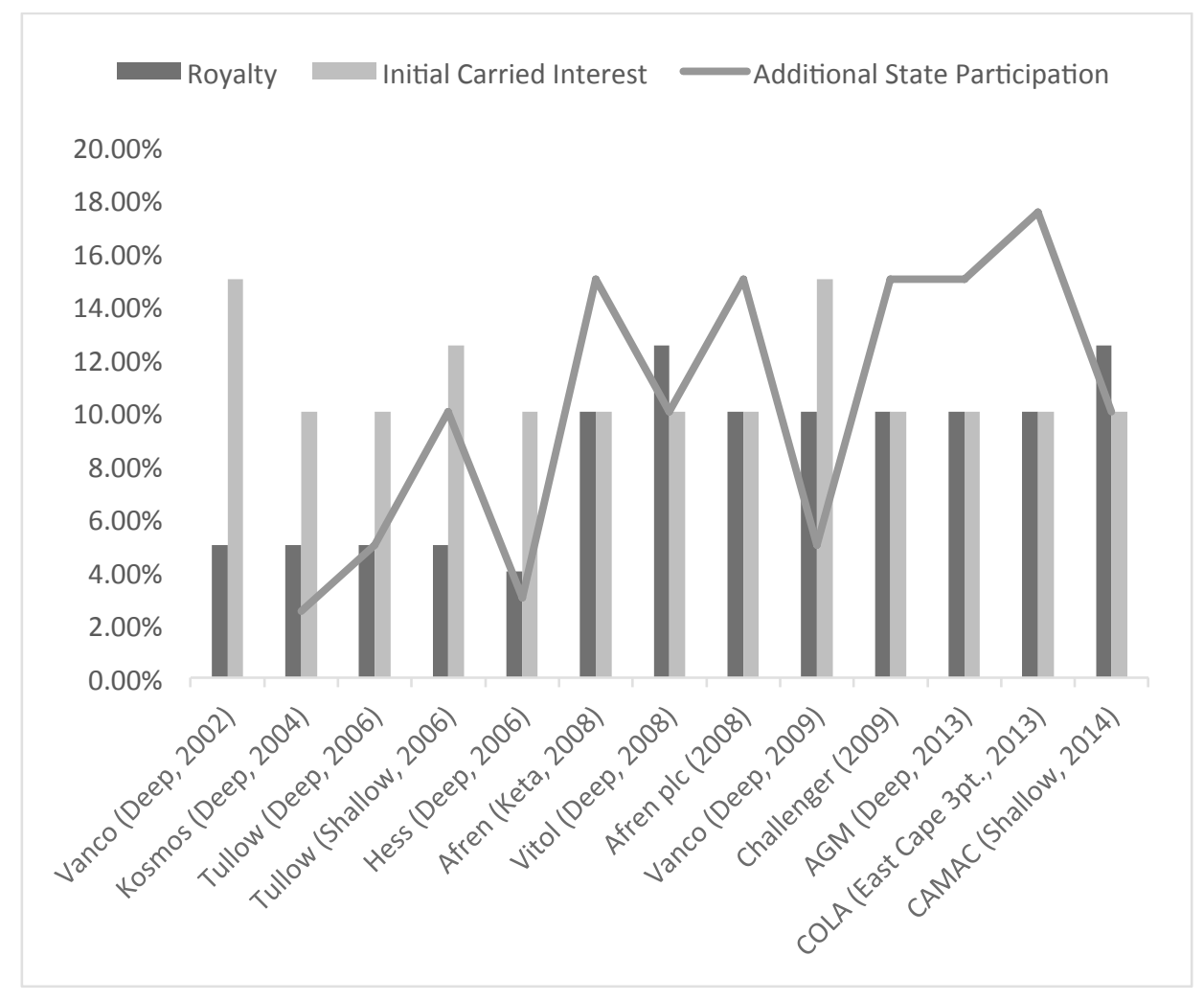

Source: Authors, based on Ghana's oil agreements, 2002-14.

\subsection{Driving a hard bargain in Uganda: The politics of embedded autonomy}

In Uganda, the Petroleum Exploration and Production Department (PEPD) was formed in 1991 as part of the Ministry for Energy and Minerals Development, an outgrowth of the Petroleum Unit that was established with World Bank support in 1985. When the NRM came to power in 1986, IOCs offered to undertake explorations for what they suspected were commercially viable quantities of oil. On discovering that Uganda lacked the expertise to undertake such efforts by itself, President Museveni eschewed offers of external support in favour of building homegrown capacity: a range of geoscientists, including some who would become PEPD commissioners, were sent to the United Kingdom and United States to retrain. With exploration efforts initially unsuccessful, the government made little further investment in PEPD, which relied instead on the patriotic and professional commitment of its leadership, along with World Bank support to recruit and train staff, and acquire enough data to attract big industry players (Kashambuzi, 2010: 3). In 2001, informal political connections enabled PEPD to extract increased government funding, later augmented by funding and capacity-building programmes from Norway, until the 
discovery of commercial quantities of oil in 2006 led the president to reinvest heavily in PEPD.

Internally, PEPD was characterised by high levels of human resource capacity: all operational and senior staff have postgraduate degrees in relevant fields, with training consolidated through regular on-the-job training, including through Norway's International Program for Petroleum Management (PETRAD), India's Oil and Natural Gas Commission and regular exposure at international conferences. International experts note of PEPD staff that, "there is no doubt that technically they are good, they are very smart, very smart" (interview, development advisor, 16 June 2014). PEPD's largely meritocratic processes of recruitment and promotion are protected from external political influence, beyond the more recent tendency to appoint officials from oil-producing regions to junior positions. Incentivised through their high salaries, allowances, technical support and considerable autonomy, staff at PEPD stress that there is also a strong emphasis on establishing a positive organisational culture that has non-material roots (interviews with PEPD staff, April and June 2014). This was instilled during the years of exploration during the 1990s, when successive commissioners were seen to share in the hardships imposed by limited funding and the tough conditions of exploring for onshore oil. Leaders seek to inculcate a patriotic sense of mission, professional norms and a strong focus on performance through regular staff meetings, training opportunities and checks on the quality of work being undertaken.

In terms of external factors, Uganda's dominant political settlement afforded PEPD a high degree of continuity and political protection. Once commercial quantities of oil were discovered in 2006, a strikingly close relationship developed between the president and senior technocrats within the PEPD. Located away from the capital on the banks of Lake Victoria, and within close proximity to State House, PEPD effectively acted as a presidential think tank on oil issues during this period. The president placed an unusually high degree of reliance and trust in their advice, deferring to their judgment on critical issues, including contracting, identifying partners and contentious discussions over the relative merits of the pipeline and refinery. This was particularly striking given that the president's general approach to the public bureaucracy over this period has to largely sidestep it in favour of 
establishing parallel structures and more personalised forms of governance (GoloobaMutebi and Hickey, 2016; Kjær, 2015), an anomaly that we return to below.

As indicated above, Uganda has been able to secure more favourable deals with IOCs. Multiple stakeholders interviewed for this project related this success directly to the capacity of the technocrats within the Ministry of Energy, and PEPD in particular. One international oil expert notes that: "I would think that there are few other governments in Africa that match the one of PEPD ... their ability to negotiate with oil companies is very advanced" (interview, 15 April 2014), whilst an IOC source states that: "We find the Ministry of Energy and Ministry of Finance (in Uganda) to be highly competent" (interview, 7 November 2013). PEPD decided against using consultants in favour of training government employees to handle negotiations with IOCs, later drawing on PETRAD's specialist training to strengthen their capacity to undertake negotiations (this included testing agreed negotiating positions through role play, not accepting bribes, and avoiding socialising during negotiations). The capacity and confidence to operate at this level arguably flowed from the initial decision by President Museveni in 1986 to resist the overtures of those IOCs offering to explore and exploit Uganda's oil and to instead start training its own geoscientists and building the technical capacity to exploit the country's sovereign wealth domestically. This move, made whilst Uganda's initial dominant party settlement was being established in 1986, is cited by one erstwhile PEPD commissioner as "probably the single most important contribution to the making of good agreements in the country" (Kashambuzi, 2010: 71-72).

The differences between each country's political settlement, and the impact that this had on the degree of long-term vision and willingness to invest in building capable and autonomous oil technocracies, offers a compelling explanation for the different quality of deals that each country was able to secure. To check against alternative readings, we directly explored the possibility that Uganda should be in a stronger bargaining position because its oil is onshore and therefore subject to a less expensive exploration process than Ghana's offshore oil. However, interviews with industry experts, including those operating in both countries, suggested that this had not been the case. In particular, the costs of offshore drilling had significantly declined in recent years, due to technological advances, whilst Uganda presented a riskier investment scenario on multiple counts, including its 
poorer quality of governance quality, the need that onshore oil creates for negotiations with landowners, the security costs of operating onshore oil installations, its relatively small deposits and the costs associated with piping Uganda's waxy oil through highly insecure regions from a landlocked country. As such, Uganda was arguably in a weaker bargaining position than Ghana and yet still managed to secure better deals.

\section{Analysis: How political settlements shape varieties of resource nationalism}

The varieties of resource nationalism that we have identified here, both between Ghana and Uganda and within Ghana over time, cannot be explained through a purely institutional analysis (e.g. Wilson, 2015). Rather, we argue that these patterns correspond more directly to the incentives and also the ideas that characterise the underlying political settlements in each context and how these change over time. This holds across the key dimensions of resource nationalism explored here, with regards to the commitment and capacity to forge and implement an ambitious fiscal regime and to invest in building highcapacity and largely autonomous oil agencies, and also the pace of production.

Secure in its dominance and with its ideological commitment to development apparently revitalised, Uganda's executive moved forward carefully, ensuring that institutional arrangements and a muscular fiscal regime were first put in place, before then securing good deals with IOCs. This contrasts markedly with Ghana's record-breaking rush to production in an unregulated environment, reflecting the shorter time horizons characteristic of more competitive clientelist settlements. ${ }^{i x}$ Ghana's fiscal regime changed over time in line with electoral dynamics and the ideological preferences of its two main parties: more neoliberal under the NPP, more resource nationalist under the NDC. The combined influence of the ideas and incentives that characterised each country's political settlement at particular points of time is particularly apparent in relation to the varying levels of commitment to building the bureaucratic capacity required to ensure a high level of state control over national resources. 
In both countries, the initial decision to invest in high-capacity oil sector agencies was made by ideologically driven political rulers operating within dominant party settlements. In Ghana, whilst the GNPC was also able to develop a high degree of technical competence in its early phase during the 1980s and 1990s, its capacity to operationalise this was undermined by the high level of politicisation emanating from its competitive clientelist settlement. This is in contrast to Uganda's more dominant party political settlement, whereby a committed political principal with a longer-term time horizon joined forces with a capable set of agents, and had the capacity to maintain this shared project over time. Whereas IOCs were clear as to where decision-making power resided in Uganda's dominant political settlement, Ghana's more fragmented political elite offered IOCs the opportunity to play leading politicians and bureaucrats off against one another (interview with energy ministry official, November 2013). According to one top-ranked GNPC official: "I have never doubted my capacity within GNPC. But does the negotiation and decisions always rest with GNPC? No" (interview, 27 August 2014). The NPP's decimation of GNPC in the early 2000s was driven by a commitment to undermining what they perceived to be a political tool, not only of the NDC's rent-seeking activities, but also its statist developmental strategy. Removing regulatory powers from GNPC and reducing its capacity to undertake commercial activities fitted directly with the NPP's ideological preference for a more market-friendly approach. On its return to power in 2008, the NDC sought to reverse both of these shifts, installing a tougher fiscal regime and re-building GNPC in ways that would reestablish both its rentier and developmental capacities (Wilson, 2015). This ebb and flow between neoliberal and resource nationalist forms of oil governance arguably reflects both the pros (the ideological choices offered by programmatic politics) and cons (policy incoherence over time) of policy making within competitive settings. ${ }^{x}$ In contrast, PEPD emerges during this period as a high-capacity government agency that has been granted the autonomy, longterm technical support and political protection required to ensure effective levels of performance (although see Hickey and Izama 2020 for an updated reading on this score).

What matters here is not merely the enforcement capacities of dominant coalitions, but also the ideological underpinnings of elite behaviour, as emphasised in the literature on developmental states ( $\mathrm{Vu}, 2007)$. Not all resource-rich countries in Africa with dominant coalitions take steps to protect the national interest in a meaningful way, as the kleptocratic 
examples of countries like Gabon and Equatorial Guinea indicate. Where they do, as with Botswana (where political dominance and democracy have co-existed for most of the postindependence period), it was the developmental and nation-building vision of the ruling coalition that underpinned the commitment to building institutions that would help avoid the natural resource curse and ensure broad-based benefits from mineral wealth (Poteete, 2009). There are some similarities here to our cases, in that the decision to build strong oil technocracies in both Ghana and Uganda was made just after new revolutionary movements had started to forge new and dominant settlements amidst revolutionary promises to transform state-society relations and promote development. This particular conjuncture - whereby major resource finds are contemporaneous with the formation of a new political and ideological settlement - has already been identified as an ideological driver of resource nationalism (Bremmer and Johnson, 2009). In the case of Uganda, this may also help to explain the apparently anomalous situation whereby the president has allowed oil sector officials a higher degree of autonomy than the wider economic technocracy, which became subject to growing levels of political interference over the late 2000s (Golooba-Mutebi and Hickey, 2016; Bukenya and Hickey, 2019). The ideational specificity of oil seems to have reshaped the president's political imagination back towards a more statist development vision for Uganda whilst also raising the spectre of the resource curse, with both prospects re-enforcing the need to adopt a carefully technocratic approach.

Our focus here on the upstream part of the oil sector in each country and also, in the main, the pre-production period, prevents us from fully exploring whether the forms of resource nationalism that emerged in Ghana and Uganda during the commodity supercycle period have or will become more or less rentier or developmental in character over time. The rhetoric is certainly developmental in both cases. However, in the case of Uganda, this needs to be set against the considerable pressures, both on and within its ruling coalition, to operate primarily in rent-seeking mode for reasons of political survival (Golooba-Mutebi and Hickey 2016), and also the important sense in which Uganda's more robust form of resource nationalism has generated so much conflict with IOCs that production seems to have become delayed indefinitely. There are clear parallels here with the case of Tanzania, where the hardened form of resource nationalism emerging over the past decade appears to have 
kept investors away (Pedersen et al., 2020). In Ghana, and after NPP's neoliberal softening of the fiscal regime swiftly attracted investors during the 2000s, the relatively soft version of resource nationalism deployed by the NDC from 2008 to 2016 seems so far to have taken both rentier and developmental forms (cf. Wilson, 2015). The NDC has envisaged a wider developmental role for GNPC and the oil sector, and there is growing evidence that it has helped generate significant resources for investment in public infrastructure and other major developmental projects (Abdulai et al., 2020). At other times, the pressures of political competition have seen both the NDC and NPP use GNPC and mineral rents in a much less strategic and arguably more populist way, as with the broad-based distribution of oil revenues, primarily to secure regime stability (Asante, 2016).

\section{Conclusion}

The institutional and political responses of Africa's new producers to the commodity supercycle of the early 21st century involved varying levels and forms of resource nationalism. This paper has shown that current efforts to both define and explain these varieties are problematic and that an ideational form of political settlements analysis can help advance understandings here. First, our findings challenge the tendency to characterise all forms of resource nationalism within Africa as both broadly the same and as being broadly rentier in character. The cases of Ghana and Uganda show that varying levels of resource nationalism exist both within and between countries, and that they might take on both rentier and developmental characteristics at the same time. Second, we challenge current efforts to explain resource nationalism in terms of either ideas (Andreasson, 2015; Bremmer and Johnston, 2009) or institutions (Wilson, 2015). This is partly because this approach can result in rather tautological explanations (e.g. countries with a rentier political economy will tend to deploy a rentier form of resource nationalism) and partly because focusing on only one or other of these drivers can only offer a partial account. Political settlements analysis can help here in that it seeks to identify the different configurations of power that generate different combinations of ideas, institutions and incentives, the ways in which they interact and the political work that they do. The ideational version of political settlements analysis developed and deployed here, then, has the potential to generate 
important insights into the nature of oil governance in Africa, and beyond. The challenge is to explore whether this approach offers a similar level of traction in relation to a wider set of countries with these (and other) types of political settlement characteristics, as well as to our two cases over time. 


\section{References}

Abdulai, A.G., Hickey, S., 2016. The politics of development under competitive clientelism: Insights from Ghana's education sector. African Affairs. 115(458), 44-72.

Abdulai, A.-G. and Mohan, G. 2019. The politics of bureaucratic 'pockets of effectiveness': Insights from Ghana's Ministry of Finance. ESID Working Paper No. 119. Manchester, UK: The University of Manchester. Available at www.effective- states.org

Abdulai, A.-G, Asante, K., Mohan, G., 2020. The 'new' Institutional politics of Ghana's hydrocarbon governance, ESID working paper. Effective States and Inclusive Development Research Centre, The University of Manchester, UK.

Acemoglu, D., Johnston, S., Robinson, J.A., 2003. An African success story: Botswana, in: Rodrick, D. (Ed.), In Search of Prosperity: Analytical Narratives on Economic Growth. Princeton University Press, Princeton, NJ, pp. 80-122.

ACEP, 2014. ACEP's statement on two oil contracts secretly rushed through parliament. Accra: Africa for Centre Energy Policy. http://www.ghanaweb.com/GhanaHomePage/NewsArchive/artikel.php?ID=304049 (accessed 8 June 2020).

Amoako-Tuffour, J., Owusu-Ayim, J., 2010. An evaluation of Ghana's petroleum fiscal regime. Ghana Policy Journal. 4, 7-34.

Andreasson, S., 2015. Varieties of resource nationalism in sub-Saharan Africa's energy and minerals markets. The Extractive Industries and Society. 2, 310-319.

Asante, K., 2016. Pathway(s) to Inclusive Development in Ghana: Oil, Subnational-National Power Relations and Ideas. A thesis submitted to the University of Manchester for the degree of Doctor of Philosophy in the Faculty of Humanities.

Bebbington, A., Abdulai, A.-G., Humphreys Bebbington, D., Hinfelaar, M., Sanborn, C., 2018. Governing Extractive Industries: Politics, Histories, Ideas. Oxford University Press, Oxford.

Behuria, P., Buur, L., Gray, H., 2017. Studying political settlements in Africa. African Affairs. 116(464), 508-525. 
Bremmer, I., Johnston, R., 2009. The rise and fall of resource nationalism. Survival. 51, 149158.

Childs, J., 2016. Geography and resource nationalism: A critical review and reframing. The Extractive Industries and Society. 3(2), 539-546.

Childs, J., Hearn, J., 2017 'New' nations: Resource-based development imaginaries in Ghana and Ecuador, Third World Quarterly. 38(4), 844-861.

De Vibe, M., 2013. Political Economy Analysis of the Oil Sector in Uganda. A Scoping Study for the International Law and Policy Institute. ILPI, Oslo.

Di John, J., Putzel, J., 2009. Political settlements: Issues paper. Governance and Social Development Resource Centre: University of Birmingham, UK.

Dijkstra, A.G., van Donge, J.K., 2001. What does the 'show case' show? Evidence of and lessons from adjustment in Uganda. World Development. 29(5), 841-863.

The Economist, 2012. Resource nationalism in Africa: Wish you were mine. 11 February. https://www.economist.com/middle-east-and-africa/2012/02/11/wish-you-weremine (accessed 28 February 2020).

Evans, P., 1995. Embedded Autonomy: States and Industrial Transformation. Princeton University Press, Princeton, NJ.

Gary, I., 2009. Ghana's Big Test: Oil's Challenge to Democratic Development. Oxfam and Integrated Social Development Centre, Accra.

George, A.L., Bennett, A., 2005. Case Studies and Theory Development in the Social Sciences. MIT Press, Cambridge, MA.

Gerring, J., 2007. Case Study Research: Principles and Practices. Cambridge University Press, New York.

Global Witness, 2014. A Good Deal Better? Uganda's Secret Oil Contracts Explained. Global Witness, London.

Golooba-Mutebi, F., Hickey, S., 2013. Investigating the links between political settlements and inclusive development in Uganda: Towards a research agenda. ESID Working Paper No. 20. Effective States and Inclusive Development Research Centre, The 
University of Manchester, UK. http://www.effective-states.org/wpcontent/uploads/working_papers/final-pdfs/esid_wp_20_goloobamutebi-hickey.pdf (accessed 8 June 2020).

Golooba-Mutebi, F., Hickey, S., 2016. The master of institutional multiplicity? The shifting politics of regime survival, state-building and democratisation in Museveni's Uganda. Journal of East African Studies. 10(4), 601-618.

Gray, H., 2019. Understanding and deploying the political settlements framework, in: Cheeseman, N., Bertrand, E., Husaini, S. (Eds.), A Dictionary of African Politics. Oxford University Press, Oxford.

Gyimah-Boadi, E., Prempeh, H.K., 2012. Oil, politics, and Ghana's democracy. Journal of Democracy. 23(3), 94-107.

Hansen, H.B., Twaddle, M., 1991. Changing Uganda: The Dilemmas of Structural Adjustment and Revolutionary Change. James Currey, London.

Heller, P. R. P., Marcel, V., 2012. Institutional Design in Low-capacity Oil Hotspots. Revenue Watch Institute.

Hertog, S., 2010. Defying the resource curse: Explaining successful state-owned enterprises in rentier states. World Politics. 62(2), 261-301.

Hickey, S., 2013. Beyond the poverty agenda? Insights from the new politics of development in Uganda. World Development. 43, 194-206.

Hickey, S., Izama, A., 2016. The politics of governing oil in Uganda: Going against the grain? African Affairs. 116 (463), 163-185.

Hickey, S. and A. Izama. 2020. The politics of governing oil after 'best-practice' reforms: Can 'pockets of effectiveness' survive within Uganda's political settlement? Extractive Industries and Society, forthcoming.

Hout, W., 2013. Neo-patrimonialism and development: Pockets of effectiveness as drivers of change. Revue Internationale de Politique Comparée. 20, 79-96.

Jepson, N. (2020) In China's wake: How the Commodity Boom Transformed Development Strategies in the Global South. New York: Columbia University Press. 
Karl, T.L., 2007. Ensuring fairness: The case for a transparent fiscal social contract, in: Humphreys, M., Sachs, J.D., Stiglitz, J.E. (Eds.), Escaping the Resource Curse. Colombia University Press, New York, pp. 256-285.

Kashambuzi, R.J., 2010. The Story of Petroleum Exploration in Uganda: 1984-2008. A Matter of Faith. IMPRO Publications Ltd, Kampala.

Keefer, P., 2007. The Resilience of Clientelism and the Political Economy of Growthsupporting Policies in Ghana. The World Bank, Washington, DC.

Kelsall, T., 2013. Business, Politics and the State in Africa: Challenging the Orthodoxies on Growth and Transformation. Zed Books, London.

Khan, M.H., 2010. Political settlements and the governance of growth-enhancing institutions. Mimeo. SOAS, London.

Khan, M.H., 2017. Political settlements and the analysis of institutions. African Affairs. Introduction to Special Online Issue.

Khan, M.H., Jomo, K.S. (Eds.), 2000. Rents, Rent-seeking and Economic Development: Theory and Evidence in Asia. Cambridge University Press, Cambridge.

Killick, T., 2008. What drives change in Ghana? A political-economy view of economic prospects, in: Aryeetey, E., Kanbur, R (Eds.), The Economy of Ghana: Analytical Perspectives on Stability, Growth and Poverty. James Currey, London, pp. 20-35.

Kjær, A.M., 2015. Political settlements and productive sector policies: Understanding sector differences in Uganda. World Development. 68, 230-241.

Kurtz, M.J., 2009. The social foundations of institutional order: Reconsidering war and the 'resource curse' in third world state building. Politics \& Society. 37(4), 479-520.

Lavers, T., 2018. Taking ideas seriously within political settlements analysis. ESID Working Paper No. 95. Effective States and Inclusive Development Research Centre, The University of Manchester, UK. http://www.effective-states.org/wpcontent/uploads/working_papers/final-pdfs/esid_wp_95_lavers.pdf (accessed 8 June 2020).

Leftwich, A., 1995. Bringing politics back in: Towards a model of the developmental state. Journal of Development Studies. 31(3), 400-427. 
Leftwich, A., 2010. Beyond institutions: rethinking role of leaders, elites, coalitions in the industrial formations of states and strategies. Forum for Development Studies. 37(1), 93-111.

Levy, B., 2014. Working with the Grain: Integrating Governance and Growth in Development Strategies. Oxford University Press, Oxford.

Lewis, P.M., 2007. Growing Apart: Oil, Politics, and Economic Change in Indonesia and Nigeria. University of Michigan Press, Ann Arbor, MI.

Lindberg, S.I. and M.K.C Morrison. 2008. Are African Voters Really Ethnic or Clientelistic? Survey Evidence from Ghana, Political Science Quarterly, 123.

Lindemann, S., 2011. Just another change of guard? Broad-based politics and civil war in Museveni's Uganda. African Affairs. 110(440), 387-416.

Macuane, J.J., Buur, L., Monjane, C.M., 2017. Power, conflict and natural resources: The Mozambican crisis revisited. African Affairs (online version). doi.org/10.1093/afraf/adx029.

Mohan, G., Asante, K.P., Abdulai, A.-G., 2018. Party politics and the political economy of Ghana's oil. New Political Economy. 23(3), 274-289.

Mosley, P., 2012. The Politics of Poverty Reduction. Routledge, London.

NRGI, 2014. Natural Resource Charter, second ed. Natural Resource Governance Institute, New York.

Oduro, F., Awal, M., Ashon, M.A., 2014. A dynamic mapping of the political settlement in Ghana. ESID Working Paper No. 28. Effective States and Inclusive Development Research Centre, The University of Manchester, UK. http://www.effectivestates.org/wp-content/uploads/working_papers/final-pdfs/esid_wp_28_oduro.pdf (accessed 8 June 2020).

Opoku, D.K., 2010. The Politics of Government-Business Relations in Ghana, 1982-2008. Palgrave Macmillan, New York.

Osei, R.D., C. Ackah, G. Domfe, and M. Danquah. 2018. Political settlements and structural change: Why growth has not been transformational in Ghana. In L. Pritchett, K. Sen 
and E. Werker (eds.), Deals and Development: The Political Dynamics of Growth Episodes. Oxford: Oxford University Press. Open access.

Pedersen, R., T. Jacob and P. Bofin. 2020. From moderate to radical resource nationalism in the boom era: Pockets of effectiveness under stress in 'new oil' Tanzania. Extractive Industries and Society, advance view. doi.org/10.1016/j.exis.2020.03.014

Phillips, J., Hailwood, E., Brooks, A., 2016. Sovereignty, the 'resource curse' and the limits of good governance: a political economy of oil in Ghana, Review of African Political Economy. 43(147), $26-42$.

PIAC. 2014. Report on Management of Petroleum Revenues for 2013. Public Interest and Accountability Committee, Accra.

Poteete, A.R., 2009. Is development path dependent or political? A reinterpretation of mineral-dependent development in Botswana. The Journal of Development Studies. 45(4), 544-571.

Portes, A., 2006. Institutions and development: A conceptual re-analysis. Population and Development Review. 32, 233-262.

Prempeh, H.K., Kroon, C., 2012. The political economy analysis of the oil and gas sector in Ghana: Implications for STAR-Ghana. Paper submitted to STAR-Ghana, Accra.

Republic of Uganda (2010). Uganda National Development Plan: Growth, employment and socio-economic transformation for prosperity. Kampala: National Planning Authority.

Rodrik, D., 2004. Getting institutions right. Mimeo. Harvard, Cambridge, MA. Available at: http://drodrik.scholar.harvard.edu/files/dani-rodrik/files/getting-institutionsright.pdf (accessed 8 June 2020).

Salimo, P., L. Buur and J.J. Macuane. 2020. The Politics of Domestic Gas: The Sasol Natural Gas Deals in Mozambique. Extractive Industries and Society, advance view.

Sheppard, E., and H. Leitner. 2010. Quo vadis neoliberalism? The remaking of global capitalist governance after the Washington Consensus. Geoforum, 41, 185-194.

Siakwah, P., 2017. Are natural resource windfalls a blessing or a curse in democratic settings? Globalised assemblages and the problematic impacts of oil on Ghana's development', Resources Policy. 52, 122-133. 
Slater, D., 2010. Ordering Power: Contentious Politics and Authoritarian Leviathans in Southeast Asia. Cambridge University Press, New York.

Taylor, I., 2014. Emerging powers, state capitalism and the oil sector in Africa, Review of African Political Economy., 41(141), 341-357.

Thurber, M.C., Istad, B.T., 2012. Norway's evolving champion: Statoil and the politics of state enterprise, in: Victor, D.G., Hults, D.R., Thurber, M.C. (Eds.), Oil and Governance: State-owned Enterprises and the World Energy Supply. Cambridge University Press, Cambridge, UK, pp. 599-654.

Tumusiime-Mutebile, E., 2010. Institutional and political dimensions of economic reform, in: Kuteesa, F., Tumusiime-Mutebile, E., Whitworth, A., Williamson, T. (Eds.), Uganda's Economic Reforms: Insider Accounts. Oxford University Press, Oxford, UK, pp. 35-51.

Tyce, M. 2020. Unrealistic expectations, frustrated progress and an uncertain future? The political economy of oil in Kenya', Extractive Industries and Society, advance view. https://doi.org/10.1016/j.exis.2020.03.003

Van Alstine, J., Manyindo, J., Smith, L., Dixon, J., Amanigaruhanga, I., 2014. Resource governance dynamics: The challenge of 'new oil' in Uganda. Resources Policy. 40, 48-58.

Vernon, R., 1971. Sovereignty at Bay: The Transnational Spread of US Enterprises. Longman, London.

Vivoda, V., 2009. Resource nationalism, bargaining and international oil companies: Challenges and changes in the new millennium. New Political Economy. 14(4), 517534.

$\mathrm{Vu}, \mathrm{T} ., 2$ 2007. State formation and the origins of developmental states in South Korea and Indonesia. Studies in Comparative International Development. 41, 27-56.

Ward, H., 2009. Resource nationalism and sustainable development: A primer and key issues. IIED, London. https://pubs.iied.org/pdfs/G02507.pdf (accessed 8 June 2020).

Watts, M. J. 2004. Antinomies of community: some thoughts on geography, resources and empire. Transactions of the Institute of British Geographers, 29: 195-216. 
Whitfield, L., 2012. Growth without economic transformation: Economic impacts of Ghana's political settlement. DIIS Working Paper No. 28. Danish Institute for International Studies, Copenhagen.

Whitfield, L., Therkildsen, O., Buur, L., Kjær, A.M., 2015. The Politics of African Industrial Policy: A Comparative Perspective. Cambridge University Press, Cambridge, UK.

Wilson, J., 2015. Understanding resource nationalism: Economic dynamics and political institutions, Contemporary Politics. 21:4, 399-416

World Bank, 2010. Ghana - gas and oil capacity building project. Project Appraisal Document. World Bank, Washington, DC.

\footnotetext{
'The other main economic argument is around bargaining obsolescence (Vernon, 1971), whereby in the early phases of resource exploitation, international firms carry much of the risk and so determine the nature of contracts, whereas when production matures, host states can more easily set the terms.

ii We present data here as close as possible to the point of oil discovery. Polity IV operates on a scale of -10 to +10 , whilst the World Governance Indicators use a scale of -2.5 to +2.5 .

iii The National Resource Governance Institute (NRGI, 2014) identifies 'getting a good deal' as being central to three of its ten key precepts for good oil governance. We define good deals as those that secure a high proportion of profits for national governments compared with the proportion secured by the oil companies, and identify data that helps to compare with our cases and others within Africa.

iv We do not have room here to fully explore the process through which Ghana eventually adopted the socalled Norway model of oil governance; this is the dealt with in a separate paper (Abdulai et al., 2020).

${ }^{v}$ All commercial oil finds in both countries are contractually subject to production-sharing agreements (rather than operating as concessions), which means that the share that governments are able to secure vis-à-vis the oil company take (after allowing for cost recovery) determines the levels of profit they can get from their oil wealth post-production.

${ }^{\mathrm{vi}}$ As discussed elsewhere, (Hickey and Izama, 2016), Uganda also largely secured its resource nationalist priorities for the sector's development within the 2014 Memorandum of Understanding, which ensured, against IOC preferences, that first oil would flow to the refinery before being used for export.

vii For one insider, GNPC does "still exhibit a high level of control over who comes there; the merit level is still very strong, especially the technical persons who cannot hide their incompetence" (interview, energy ministry official, 29 August 2014).

viii See Ghana News Agency, 25 August 2013. Capacity building explains rise in GNPC expenditure - Director. http://www.ghananewsagency.org/economics/capacity-building-explains-rise-in-gnpc-expenditure-director-63843 (accessed 8 June 2020).

${ }^{\mathrm{ix}}$ These pressures have continued to shape the interface of deal making and institutional arrangements in Ghana; the rapid award of promising oil blocks to relatively inexperienced companies during 2013-14 took place under a 'certificate of urgency'. Critics suggest that ruling elites facing the likelihood of an electoral turnover in 2016 were keen to make deals favourable to themselves while delaying the passage of a revised Exploration and Production bill, which commits the country to competitive bidding processes of oil blocs (interview, civil society activist, 26 August 2014; also ACEP, 2014).

${ }^{x}$ We would not expect programmatic considerations to weigh as heavily in competitive clientelist settings where political competition and the exchange of power had not become institutionalised as part of the 'deal'.
} 